\title{
Down the Drain: A Comparison of the Impact on Biodiversity of Groundwater Law IN TEXas AND Rio GRANDE DO SUL
}

\section{Shaun S. Schottmiller}

\section{INTRODUCTION}

The starting point for this project is the bifurcated system of water management in the United States, specifically Texas, which treats surface water and groundwater under different regimes. This bifurcation is not present in Brazil and the state of Rio Grande do Sul due to a federally recognized unit of administration that encompasses the entire hydrological basin, rather than administering rivers, swamps, and aquifers separately. While much debate has focused on the takings aspect of a change in groundwater law, little debate has focused on the affects on biodiversity that would occur from a change in groundwater law. Increasingly science has shown that water, in all its forms, is interconnected in such a manner that only through a unified, integrated, approached, taking into account the entire hydrological cycle, can we achieve effective water management and environmental protection.

The note proceeds as follows. Section II provides a hydrological primer to provide the necessary scientific context through which the legal discussion will proceed. Section III discusses the varying surface water regimes in the United States. Section IV details four of the broad families of groundwater regimes in the United States, while Section V focuses specifically on the groundwater regime in Texas. Section VI analyzes the special case of the Edwards Aquifer in Texas. Section VII examines the shortcomings of the Federal Endangered Species Act, as it is the preferred tool for limiting groundwater extraction in Texas. Section VIII discusses Texas Senate Bill 1 and the attempt to redesign of Texas water law in 1999. From section IX the discussion switches to Brazil and the constitutionalization of Brazilian environmental law as a framework for understanding the water regime. Section $\mathrm{X}$ introduces groundwater law in Brazil generally, while section XI focuses specifically on the groundwater laws of Rio Grande do Sul. 


\section{HYDROGEOLOGY PRIMER}

In order to understand how Texas groundwater law fails to adequately protect biodiversity, we must understand the interaction between groundwater and biodiversity. I divide this section into three parts. First, I will present a short overview of the hydrologic cycle. Next, I will briefly discuss the two basic pathways in which groundwater and surface water interact. Finally, I will discuss how biodiversity is affected by these interactions.

\section{A. The Hydrologic Cycle and Groundwater}

The hydrologic cycle describes the continuous flow of water in its various forms liquid, solid, gas, and vapor - from atmosphere to ground to ocean. Water evaporates off the oceans and is moved by winds over land. As the moisture level in the air increases, the vapor become precipitation and falls to the ground. Some of the water on the ground will evaporate and some of the water will remain on the Earth. Plants will take some of the water. Some of the water returns to the oceans through rivers and streams. Finally, some of the water seeps into the ground. This seepage of water into the ground is called recharge. It is through this recharge that aquifers are replenished.

The amount of techarge that reaches the aquifer is dependent upon the geological formation surrounding the aquifer. ${ }^{1}$ The more permeable the layer of rock that is above the aquifer, the more it will be able to recharge. Impermeable rock will result in zero recharge for the aquifer, thus water extraction will completely empty the aquifer.

\section{B. Groundwater-Surface Water Connections}

The term groundwater includes all water located below the surface. ${ }^{2}$ An aquifer is defined as "as subsurface waterbearing geological formation from which significant quantities of water may be extracted." 'The terms groundwater and aquifer are often used interchangeably, and I will do so in this article. There are two general ways in which groundwater can affect surface water. ${ }^{4}$ The aquifer can feed the stream, a gaining stream (Figure 1a), or the aquifer can

1 See Gabriel Eckstein and Yoram Eckstein, A Hydrogeolocial Approach to Transboundary Ground Water Resources and International Law, 19 Am. U. Int'l. L. Rev. 201, 211-217 (2003) for a more detailed discussion of the geology of aquifers.

2 Specifically groundwater only refers to the water found in saturated zones of geological formations [see Ralph C. Heath, Basic Ground-Water Hydrology, U.S. Geological Survey Water-Supply Paper 2220, 4 (1987)]. Under Texas law, groundwater is defined as "water percolating below the surface of the Earth." [Tex. Water Code Ann. \$36.001(5) (Vernon Supp. IA 2002)].

3 Robert Hayton and Albert Utton, Transboundary Groundwaters: The Bellagio Draft Treaty, 29 Natural Resources Journal, 677, 678 (1989).

4 Surface water refers to water above ground, such as streams, lakes, wetlands, bays and oceans. (see Thomas C. Winter, Judson W. Harvey, O. Lehn Franke, and William M. Alley, Ground Water and Surface Water: A Single Resource, U.S. Geological Survey Circular 1139, 2. (1998). 
be fed by the stream, a losing stream (figure 1b). ${ }^{5}$ When surface water and groundwater are connected, extraction of groundwater can have serious consequences on the surface water. If a stream is feeding the aquifer, pumping will result in an increased flow from the surface water to the aquifer, thus lower in the surface water level. ${ }^{6}$ If an aquifer is feeding the surface water some of the water that would have been discharged into the surface body will be captured, likewise diminishing the surface water level. ${ }^{7}$ As discussed above, the permeability of the rock that overlies the aquifer will affect the connectedness of the groundwater and the surface water.

The plight of the Santa Cruz River presents a vivid example of the interconnectedness of groundwater and surface water. ${ }^{8}$ The Santa Cruz River nurtured what was once fertile land for the Hohokam, the Tohono O'odham, and Spanish missionaries. Eventually, the city of Tucson was established on the Santa Cruz. As Tucson grew in the 1900 s, groundwater pumping increased. Quickly, groundwater pumping outpaced recharge. Recharge from rain and snow that fell on nearby mountains added about 140,000 acre-feet per year (afy) to the underlying aquifer. ${ }^{9}$ As the population of Tucson grew from 1940 to 2000, groundwater extraction accelerated from 50,000 afy to 330,000 afy. ${ }^{10}$ The Santa Cruz has run dry as the aquifer no longer contains enough water to feed it.

\section{Groundwater Affecting Biodiversity}

Biodiversity and groundwater interact both on and below the surface. A number of ecosystems rely on groundwater. Geology and other factors determine the reliance an ecosystem has on groundwater, but the groundwater does supply minerals as well as moisture to the ecosystem. ${ }^{11}$ Ecosystems in arid climates, such as West Texas, often are more reliant on groundwater than those in climates where freshwater is more pervasive. ${ }^{12}$ There are a number of types of groundwater dependent ecosystems.

Groundwater can feed into surface bodies, such as wetlands, and, together with surface water, create an ecosystem of its own. ${ }^{13}$ While differentiating between groundwater and surface water may be difficult, these ecosystems the groundwater component is still crucial to the functioning of the ecosystem.

$I d$, at 9.

Id. at 14 .

7 Id. at 14 .

8 See Robert Glennon, Water Follies: Groundwater Pumping and the Fate of America's Fresh Waters, 3550 (2002). Glennon's book has numerous examples of the effects of groundwater extraction on a variety of surface water bodies.

9 Id. at 45.

${ }^{10}$ Id.

${ }^{11}$ Friends of the Earth, Groundwater Dependent Eco-Systems (May 28, 1999), available at Nature Conservation Council of New South Wales, http://wwwwnccnsw.org.au/water/projects/Groundwater water.html (last accessed February 24, 2004).

12 Id.

${ }^{13} \mathrm{Id}$. 
Groundwater is also an important component in riparian and terrestrial vegetation ecosystems.$^{14}$ Although these ecosystems are mainly dependent upon surface waters, during times of drought, these ecosystems need to access aquifers for fresh water..$^{15}$ Declining water tables, primarily through groundwater extraction, can be particularly devastating on these ecosystems, causing dehydration or water-logging through changes in water salinity. ${ }^{16}$ In the case of the Santa Cruz River, the "draining" of the river resulted in the disappearance of riparian cottonwood, willow, and mesquite trees as well as the disappearance of deer, coyotes, javelinas, mountain lions, raccoons, foxes, rabbits, and squirrels, all of which relied on the Santa Cruz as a source of water. ${ }^{17}$

The hyporheic zone is a fluctuating zone between the surface water and the deeper groundwater. ${ }^{18}$ This zone provides habitat for many invertebrates as groundwater supplies nutrients and surface water provides dissolved oxygen. ${ }^{19}$ This ecosystem is particularly vulnerable as groundwater contamination and extraction as well as surface water pollution can disrupt its equilibrium. ${ }^{20}$

Additionally, ecosystems can solely exist within in aquifer. Hypogean ecosystems, as they are called, are quite interesting due to the lack of light in the habitat and their vulnerability to human induced change. ${ }^{21}$ The Edwards Aquifer represents a notable example of this type of ecosystem with the Texas blind salamander, the fountain darter and other species.

\section{SURFACE WATER LAW IN THE UNITED STATES AND TEXAS}

In order to understand how law in the United States, and Texas in particular, fails to adequately address the interconnectedness of groundwater and surface water, we must understand how each of these areas of law function. This section addresses surface water law, while the next section addresses groundwater law.

The ownership of surface water in the United States is governed at the state level. There are two main regimes that determine who owns what water: riparianism and prior appropriation..$^{22}$ Generally, Eastern states adhere to the riparian regime while Western states

${ }^{14} I d$.

${ }^{15}$ Id.

${ }^{16} \mathrm{Id}$.

${ }^{17}$ Glennon, supra note 8, at 48-49.

${ }^{18}$ Friends of the Earth, supra note 11.

${ }^{19}$ Id.

${ }^{20} I d$.

${ }^{21} I d$.

${ }^{22}$ Many states have adopted a "mixed" system which incorporates aspects of both riparianism and prior appropriation. These mixed systems typically protect minimal (domestic use) riparian rights and apply priority of appropriation for the remainder of water in the stream. 
(those west of the hundredth meridian) adhere to the prior appropriation regime. ${ }^{23}$ In this section I provide an overview of the two regimes that govern surface water in the United States, followed by a brief discussion of Texas surface water law in particular.

\section{A. Riparianism}

Riparianism was imported to the early United States from English common law. The English law relied on the natural flow doctrine which allowed each riparian to teceive the flow of the stream "undiminished as to quality or quantity" and to seek redress even in the absence of a harm. ${ }^{24}$ Additionally, riparians were limited to on-tract uses only. This model worked well in the pre-industrial era, but as industries began to tely on water to power mills, the natural flow doctrine was seen as impeding growth.

American courts in the early nineteenth century began to chip away at the natural flow doctrine in order to promote industrialization. In Tyler v. Wilkinson, the circuit court for the district of Rhode Island rejected the right of riparianism to receive the natural flow of the stream without diminution. ${ }^{25}$ This right was seen as a brake on development as it effectively banned all diversions from the stream. The same year, the Supreme Court of Vermont dealt another blow to the natural flow doctrine in the United States. ${ }^{26}$ In a dispute over the installation of a new mill upstream from a mill already in operation, the court stated that strict adherence to the natural flow doctrine would allow the first miller on a stream to control the flow of the entire stream, thus inhibiting production. ${ }^{27}$

íne limitation on undiminished water quality was also whittled away by early court decisions. In Snow v. Parsons, the Vermont Supreme court eschewed the strict water quality standard of the natural flow doctrine for a reasonableness standard. ${ }^{28}$ In Snow, a tannery was charged with diminishing the quality of a stream. The court stated that the relevant test is "[i]f it essentially impairs the use below, then it is unreasonable and unlawful, unless it is a thing altogether indispensable to any beneficial use to every point of the stream., ${ }^{29}$ The Pennsylvania Supreme Court summed up the judicial mindset during the industrial period by stating that "[ $[$ ]he law should be adjusted to the exigencies of the great industrial interests of the Commonwealth...The proprietors of large and useful interests should not be hampered or hindered for frivolous or trifling causes." ${ }^{30}$

${ }^{23}$ Joseph L. Sax, Barton H. Thompson, Jr., John D. Leshy, and Robert H. Abrams, Legal Control of Water Resources: Cases and Materials 4-5, 20 (3d ed. 2000).

${ }^{24}$ Sax et al, supra note 23 , at 22 ,

2524 F. Cas. 472 (C.C.R.I. 1827).

${ }^{26}$ Martin v. Bigelow, 2 Aik. 184 (Vt. 1827).

${ }^{27}$ Id. at 475.

${ }^{28} 28$ Vt. 459 (1856)

${ }^{29}$ Id. at 462.

${ }^{30}$ Sanderson v. Pennsylvania Coal Co., 86 Pa, 401, 408 (1878). 
Modern riparian doctrine generally relies on the Restatement (Second) of Torts. Section 850 states that "[a] riparian proprietor is subject to liability for making an unreasonable use of the water... that causes harm to another riparian proprietor's reasonable use of water." 31 Reasonable use is determined by a number of factors that include: the purpose of the use; the economic value of the use; the social value of the use; and the extent and amount of harm it causes ${ }^{32}$ Riparianism has evolved into a general regime of correlative rights.

\section{B. Prior Appropriation}

The Prior appropriation doctrine originated in the western half of the United States. Prior appropriation is premised on the "first in time, first in right" concept. ${ }^{33}$ There are four elements in acquiring an appropriative right, (1) there must be unappropriated water in a (2) natural stream, and the appropriator must (3) divert this water and (4) put it to beneficial use. ${ }^{34}$ The first element simply requires that the appropriator is not taking water on which another party has a claim. The second element, a natural stream, is defined as:

A stream of water flowing in a definite channel, having a bed and sides or banks, and discharging itself into some other stream or body of water. The flow of water need not be constant, but must be more than mere surface drainage occasioned by extraordinary causes; there must be substantial indications of the existence of a stream, which is ordinarily a moving body of water. ${ }^{35}$

The definition of a natural stream really only excludes groundwater and seepage or springs. The third element, diversion, can be physical diversion of water from the stream via a ditch, but many courts do not require physical diversion, simply using the water from the stream can be a "diversion."

The fourth element, beneficial use, has been the object of much debate in prior appropriation states. Most states have codified the definition of "beneficial use." ${ }^{17}$ Texas defines beneficial use as:

${ }^{31}$ Restatement (Second) of Torts \850 (1979).

${ }^{32}$ Restatement (Second) of Torts $\$ 850$ A (1979).

${ }_{33}$ See A. Dan Tarlock, Prior Appropriation: Rule, Principle, or Rhetoric?, 76 N. Dak. L. Rev. 881 (2000) for an review of and issues related to Prior Appropriation doctrine.

${ }^{34}$ Sax, et al., supra note 23, at 111-2.

${ }^{35}$ Hutchinson v. Watson Slough Ditch Co., 16 Idaho 484, 488 (1909).

${ }^{36}$ See State v. Morros, 766 P.2d 263 (Nev. 1988) and Steptoe Live Stock Co. v. Gulley, 53 Nev. 163 (1931).

${ }^{37}$ See Janet C. Neuman, Symposium on Water Law: Beneficial Use, Waste, and Forfeiture: The Inefficient Search for Efficiency in Western Water Law, 28 Envtl. L. Rev. 919, fn1 (1998). 
"the amount of water which is economically necessary for a purpose authorized by this chapter, when reasonable intelligence and reasonable diligence are used in applying the water to that purpose and shall include conserved water." 38

The California Water Code, on the other hand, devotes a large portion in defining what actions and what considerations may be included in a "beneficial use" determination: instream use; public interest; water transfers..$^{39}$ Generally, beneficial use includes domestic uses as well as agrarian and industrial without excessive waste.

Prior appropriation systems in most states are currently administered by a permit system. State statutes set out the requirements for obtaining a permit. These statutes typically require an application for the permit ${ }^{40}$, notice of the application to potentially interested parties ${ }^{41}$, and the possibility of a hearing if there is a protest ${ }^{42}$. Permits will specify the date of the appropriation, the amount to be appropriated and when it can be appropriated.

\section{Surface Water Law in Texas}

In $1889^{43}, 1895^{44}$, and $1913^{45}$, the Texas Legislature adopted the prior appropriation system for Texas. Although these laws brought the prior appropriation doctrine to Texas, they did not abolish preexisting riparian rights; they simply made all future water rights contingent on prior appropriation through the permitting process. ${ }^{46}$ The Texas Water Code states that an application for a water permit may be granted if there is (1) unappropriated water ${ }^{47},(2)$ the proposed appropriation is for beneficial use, ${ }^{48}$ does not impair existing water rights or riparian rights, ${ }^{49}$ is not detrimental to the public welfare, ${ }^{50}$ considers the effects on bays, estuaries, instream use, water quality, groundwater, and fish and wildlife habitats, ${ }^{51}$ is consistent with state and regional water plans, ${ }^{52}$ and (4) reasonable diligence will be exercised to reduce waste and achieve conservation..$^{53}$

\footnotetext{
38 Texas Water Code $\$ 11.002(6)$.

39 California Water Code $\int \$$ 1240-1244.

40 i.e., California Water Code, Ch. 2 .

41 i.e., California Water Code, Ch. 3.

42 i.e., California Water Code, Ch. 4 and Ch. 5.

43 Act approved Mar. 19, 1889, 21st Leg. R. S., ch. 88 \$ 1-17, 1889 Tex. Gen. Laws 100.

44 Act approved Mar. 21, 1895, 24th Leg. R. S., ch. 21 \& 1, 1895 Tex. Gen. Laws 21.

45 The Burges-Glasscock Act, Act of April 9, 1913, 33d Leg., R. S., ch 171, 1913 Tex. Gen. Laws 258.

46 Frank Skillern, Texas Water Law, 37-8 (1993).

${ }^{47}$ Texas Water Code $\$ 11.134$ (b)(2).

${ }_{48}$ Texas Water Code $\$ 11.134(\mathrm{~b})(3)(\mathrm{A})$.

49 Texas Water Code $\$ 11.134(\mathrm{~b})(3)(\mathrm{B})$.

so Texas Water Code $\$ 11.134(\mathrm{~b})(3)(\mathrm{C})$.

51 Texas Water Code $\$ 11.134(\mathrm{~b})(3)(\mathrm{D})$.

52 Texas Water Code $\$ 11.134(\mathrm{~b})(3)(\mathrm{E})$.

53 Texas Water Code $\$ 11.134(\mathrm{~b})(4)$.
} 
Here we see that surface water use in Texas addresses a number of issues both economic (waste) and environmental (fish and wildlife). The permit processes even addresses the possible effects of surface water appropriations on groundwater. We will se that Texas groundwater law does not incorporate these same considerations.

\section{GROUND WATER LAW IN THE UNITED STATES}

While surface water is generally governed by two regimes, gtoundwater regimes in the United States generally are governed by one of five regimes: American reasonable use, correlative rights, Restatement (Second) of Torts reasonable use, prior appropriation, and absolute ownership (or rule of capture). American reasonable use doctrine places only two limitations on groundwater use: the water must be put to a reasonable use and the use must be in the overlying tract. ${ }^{54}$ The Supreme Court of Pennsylvania sums up the basic tenet of American reasonable use by stating that a property owner "may not concentrate... waters and convey them off his land if the springs or wells of another are impaired." 55

Correlative rights doctrine, as the name implies, entails a sharing of water between the owners of the land overlying the groundwater supply. Parties wishing to use the water off-tract have their rights subjugated to any on-tract users; thus, off-tract use is only permitted if there is "surplus" water (defined as recharge less current withdrawals). ${ }^{56}$ In Katz v. Walkinshaw, the California Supreme Court concluded that the doctrine of correlative rights was superior to that of absolute ownership because it provided greater incentive for investment. ${ }^{57}$ Overlying owners wishing to use water on their land should each be given a "fait and just proportion" of the water if there is insufficient water for all. ${ }^{58}$

The Restatement (Second) of Torts, although a liability rule, acts as a rule of allocation by holding a groundwater extractor liable for unreasonable harm to others. ${ }^{59}$ Section 858 of the Restatement lays out the liability for ground water usage ${ }^{60}$ A landowner who extracts groundwater is not liable for harm to another unless the pumping lowers the water table or water pressure, ${ }^{61}$ exceeds the pumper's reasonable share of the groundwater, ${ }^{62}$ or has a direct effect upon a watercourse or lake and unreasonably causes harm to a person entitled to use that watercourse or lake. ${ }^{63}$ Unlike the American reasonable use doctrine and

\footnotetext{
${ }^{54}$ Sax et al., supra note 23 , at 364 .

${ }^{55}$ Rothrauff v. Sinking Spring Water Co., 339 Pa. 129, 134 (1940).

${ }^{56}$ Sax et al., supra note 23 , at 364 .

${ }^{57} 141$ Cal. 116, 133 (1903).

${ }^{58} \mathrm{Id}$. at 136.

${ }^{59}$ Sax et al., supra note 23 , at 365.

${ }^{60}$ Restatement (Second) of 'Torts $\$ 858$ (1979).

${ }^{61} I d$. at $\int 858(1)(\mathrm{a})$.

${ }^{62} I d$. at $\$ 858(1)(\mathrm{b})$.

${ }^{63} \mathrm{Id}$. at $\int 858(1)(\mathrm{c})$.

${ }^{64}$ Hinton v. Little, 50 Idaho 371 (1931).
} 
the correlative rights doctrine, the Restatement does not limit usage to on-tract or even favor on-tract usage. It does, though, incorporate liability that could be utilized as a cause of action to protect biodiversity. If the groundwater pumping significantly and unreasonably affects a stream or lake, then an action can be brought, but this action must be brought on behalf of someone who has a right to use that stream or lake. This presents a hurdle for the use of liability under the Restatement to protect biodiversity, but it provides more of an opportunity to do so than the above mentioned regimes.

Prior appropriation for groundwater functions similarly to prior appropriation for surface water. It is premised on the "first in time, first in right" adage. The Supreme Court of Idaho was the first adopted the regime for groundwater in $1931 .^{64}$ Although the groundwater doctrine operates in many ways like it does for surface water, there are a few different issues when groundwater is addressed. One important one involves the speed of groundwater flow. Groundwater flows much slower than surface water, so the effects of "junior" appropriators on "senior's" rights may not be felt for many months or even years. In this case it is difficult for the senior the halt the junior's pumping so that the senior can be guaranteed his share of the water. This doctrine does not address the effects on biodiversity of pumping. It simply is designed to allocate water between pumpers.

The final regime, absolute ownership, or rule of capture, is only practiced in Texas. As such it is address in the following section.

\section{TEXAS GROUNDWATER LAW}

To extract groundwater Texas only requires an individual own the surface property and own a well on the property. Once these two conditions have been met, the individual may extract an unlimited amount of groundwater. The Texas Rule of Capture has been much maligned, ${ }^{65}$ but the courts have been reluctant to alter the one-hundred-year-old rule, preferring to shift that task to the Legislature.

\section{A. Development of the Rule of Capture}

In 1904, the Texas Supreme imported the English common law rule of absolute domain to Texas. ${ }^{66}$ Absolute dominion allows the surface owner to extract the groundwater

${ }^{65}$ See Stephanie E. Hayes Lusk, Texas Groundwater: Reconciling the Rule of Capture with Environmental and Community Demands, 30 St. Mary's L.J. 305 (1998); Eric Opiela, The Rule of Capture in Texas: An Outdated Principle Beyond Its Time, 6 U. Denv. Water L. Rev. 87 (2002); Robert R.M. Verchick, Dust Bowl Blues: Saving and Sharing the Ogallala Aquifer, 14 J. Envtl. L \& Litig. 13, 21 (1999).

${ }^{66}$ Houston \& T.C. Ry. Co. v. East, 81 S.W. 279 (Tex. 1904) (adopting Acton v. Blundell, 152 Eng. Rep. 1223 (Ex. 1843)).

${ }^{67}$ See id. 
under the property regardless of the effects on neighboring properties, provided the surface owner did not do so in waste or out of malice. ${ }^{67}$ The court based its rationale on the conjecture that the movements of groundwater "are so secret, occult, and concealed that an attempt to administer any set of legal rules in respect to them would be involved in hopeless uncertainty, and would, therefore, be practically impossible." ${ }^{368}$ East continues to form the basis of groundwater in Texas even though, as shown above, science has greatly expanded our knowledge of groundwater and its role in the hydrologic cycle.

Shortly after the East decision, Texans understood the ill affects on water management that could follow from the rule of capture. ${ }^{69}$ In response, the Texas Legislature adopted the Conservation Amendment to the Texas Constitution in 1917. ${ }^{70}$ The Amendment gave the Legislature the authority to pass laws creating conservation districts and water regulations to protect the water resources in the state. ${ }^{71}$ Although given the power to regulate groundwater extraction, the Legislature failed to take any action in the following decades.

In 1949, The Legislature adopted the Texas Underground Water Conservation Act which codified the Rule of Capture. ${ }^{72}$ The Act recognizes that " $[t]$ he ownership and rights of the owner of the land, his lessees and assigns, in underground water." ${ }^{\prime 73}$ The Act does not address the issue of groundwater management or conservation.

Following the floods and droughts of the 1950s, the Legislature enacted the 1967 Water Rights Adjudication Act. ${ }^{74}$ The Act allows the state to regulate surface waters when necessary, but leaves groundwater outside the scope of the Act. Once again, the Legislature failed to address the incompatibility of the rule of capture with water conservation.

The courts and the Legislature have placed some restrictions on the ability of land owners to extract groundwater, but these limitations are slight and often difficult to prove. One limitation is that a land owner cannot extract water with malice in order to injure a neighbor. Malice is difficult to prove and has not been an issue in a Texas groundwater case. $^{75}$ Waste, though, is a more often cited limitation on the rule of capture. In City of Corpus Christiv. City of Pleasanton, the Texas Supreme Court narrowed the scope of this limitation. ${ }^{76}$ The city of Corpus Christi's extraction of water from an artesian well and

\footnotetext{
${ }^{68}$ Id at 280 (quoting Frazier v. Brown, 12 Ohio St. 294, 311 (1861)).

${ }^{69}$ See TEX. CONST. art. XVI, $\ 59$ interp. commentary (Vernon 1993).

${ }^{70}$ TEX. CONST, art. XVI, $\$ 59$.

${ }^{71}$ TEX. CONST, art. XVI, $\$ 59$ (b).

72 Texas Water Code Act Amending Chapter 25, ch. 306, 1, 1949 Tex. Gen. Laws 559 (recodified in TEX. WATER CODE ANN. $\$ 36.002$.

${ }^{73} \mathrm{Id}, 1,3 \mathrm{c}(\mathrm{D})$.

${ }^{74}$ Act of April 13, 1967, 60th Leg., R.S. ch. 45, 1967 Tex. Gen. Laws 86 (Vernon) (codified as TEX. WATER CODE ANN. \$11.301-.341.

${ }^{75}$ See Opiela, supra note 65, at 101.

${ }^{76} 154$ Tex. 289 (1955).

${ }^{77}$ ld. at 294 .

${ }^{78}$ Id. at 298.
} 
transportation of the water along a surface watercourse was upheld. The court held that the waste limitation only pertained to use of the water, not transport of the water. ${ }^{77}$ Under this definition, dissenting Justice Griffin argues, the loss of 9,999,999 gallons is permitted, so long as one gallon is put to lawful use. ${ }^{78}$

The Supreme Court stripped away some of the rule of capture in Friendswood Development Co. v. Smith-Soutbwest Industries, Inc..$^{79}$ Due to subsidence problems along the Texas coast, the Legislature established the Harris-Galveston Coastal Subsidence District (HGCSD) to oversee groundwater removal. Friendswood Development sued SmithSouthwest Industries claiming subsidence caused by defendant's groundwater pumping. The court held that the injury occurred before the establishment of the HGCSD, thus no relief was granted to Friendswood Development. ${ }^{80}$ At the time of the injury, the law allowed land owners to extract groundwater without liability to neighboring land owners. ${ }^{81}$ After the opinion becomes final, the court adds, "if the landowner's manner of withdrawing ground water from his land is negligent... and such conduct is a proximate cause of the subsidence of the land of others, he will be liable for the consequences of his conduct." ${ }^{182}$ The court, thus, adds negligence to the short list of limitations on the rule of capture.

\section{B. Deference to Legislature}

Increasingly the scientific community has shown that groundwater and surface water can, and often are, linked, such that actions affecting one source may be felt by the other. ${ }^{83}$ The courts have recognized this fact, but still refuse to alter the present rule of capture. Instead, the courts punt, stating that the issue is one for Legislative authority, not judicial authority. In Pecos County Water Control E Improvement District No. $1 \mathrm{v}$. Williams, we see an early argument based on the groundwater-surface water connection. ${ }^{84}$ The county sued to enjoin Williams from pumping groundwater from his property. The courity based its argument on the detriment effect the pumping would have on Comanche Springs. The El Paso Court of Civil Appeals was not persuaded by the evidence of a connection between Williams' pumping of groundwater and the spring's water level. ${ }^{85}$ The court, thus, held for Williams upholding the Rule of Capture.

\footnotetext{
79 276 S.W.2d 21 (Tex. 1978).

${ }^{80}$ Friendswood, 276 S.W.2d at 22.

${ }^{81} I d$. at 27.

${ }^{82} I d$. at 30 .

${ }^{83}$ See II. Hydrogeology Primer above.

${ }^{84} 271$ S.W.2d 503 (Tex. Civ. App. - EI Paso 1954, writ ref'd n.r.e.).

${ }^{85} \mathrm{Id}$. at 508 .

${ }^{86}$ Beckendorff v. Harris Galveston Coastal Subsidence District, 558 S.W.2d 75 (Tex. Civ. App.-Houston [14th Dist.] 1977, writ ref'd n.r.e.).

${ }^{87} \mathrm{Id}$. at 81 .
} 
As mentioned above, the HGCSD was recreated to address the subsidence problem that groundwater extraction was causing along the Texas coast. In 1977 residents filed suit claiming that the Act establishing the HGCSD was unconstitutional. ${ }^{86}$ The appeals court upheld the constitutionality of the Act and stated that any action to eliminate a "perceived evil" should be taken by the Legislature. ${ }^{87}$

In Denis v. Kickapoo Land Co., The Austin Court of Appeals ruled for a land owner who was extracting groundwater before it reached Kickapoo Springs. ${ }^{88}$ Kickapoo Springs, in turn, fed Kickapoo Creek. The court reasserted the right of the land owner to his groundwater, even though the water would eventually feed a creek. Faced with yet another instance of the absolute groundwater rights detrimentally affecting surface waters and, in turn, downstream users, the court refused to alter the basic rule.

Recently, the Texas Supreme Court once again upheld the rule of capture and inferred that the legislature needed to take action. In Sipriano v. Great Springs Waters of America, Inc. a/k/a Ozarka Natural Spring Water Co., the plaintiffs sued Ozarka for damages after their wells ran dry. ${ }^{89}$ Ozarka had been pumping 90,000 gallons per day, seven days a week from land neighboring the plaintiffs. ${ }^{90}$ The court reasoned that the people of Texas had the ability to alter groundwater rules through the democratic process, as they recently did with Senate Bill 1 (see below), and until it was apparent that this legislative action was ineffective, water-use regulation should not be governed by "judicial fiat."

\section{EDWARDS AQUIFER: ENVIRONMENTAL MANAGEMENT OF GROUNDWATER FOR ENVIRONMENTAL PURPOSES}

We have seen how the Texas courts generally have been reluctant to reconcile the scientific evidence of groundwater-surface water linkage with the rule of capture. One area in which the courts have addressed this issue is with respect to the Endangered Species Act (ESA) and the Edwards Aquifer (Aquifer). ${ }^{92}$ The Aquifer is a large groundwater formation in south-central Texas that is source for all of San Antonio's drinking water. The Aquifer

${ }^{88} 771$ S.W.2d 235 (Tex. App.-Austin 1989, pet. denied).

${ }^{89} 1$ SW3d 75 (Tex. 1999).

${ }^{90}$ Id. at 75 .

${ }^{91} I d$. at 80 .

${ }_{92}$ See Todd H. Votteler, The Little Fish That Roared: The Endangered Species Act, State Groundwater Law, and Private Property Rights Collide over the Texas Ea'wards Aquifer, 28 Envtl. L. 845 (1998) for a more in depth account of this topic.

${ }_{93}$ San Marcos/Comal Recovery Team, U.S. Fish \& Wildlife Serv., San Marcos and Comal Springs and Associated Aquatic Ecosystems (Revised) Recovery Plan 6 (1996).

${ }_{94}$ No. MO-91-CA-069, 1993 WL 151353, at*1 (W.D. Texas, Feb. 1, 1993).

${ }^{95}$ Id. at $* 19$. 
feeds both Comal Springs and San Marcos Springs, home to two of the richest aquatic ecosystems in terms of organism diversity. ${ }^{93}$ This Aquifer has become the frontline of the debate about groundwater rights and environmental management in Texas.

\section{A. Sierra Club v. Lujan}

In Sierra Club v. Lujan, the Sierra Club and other plaintiffs sued to enjoin the Secretary of the Interior and the United States Fish and Wildlife Service (USFWS) from pumping from the Aquifer under certain conditions and to implement a recover plan for the numerous endangered species within the Aquifer. ${ }^{94}$ The court ruled in favor of the plaintiffs, finding that the USFWS failed to establish minimum springflow requirements to protect the endangered species in the Aquifer. ${ }^{95}$ The court called upon the Texas legislature to establish an adequate state plan before Federal intervention to protect the endangered species. ${ }^{96}$

The Texas legislature subsequently enacted Senate Bill 1477 establishing the Edwards Aquifer Authority (EAA). ${ }^{97}$ The purpose of the EAA is to "ensure that...the continuous minimum springflows of the Comal Springs and the San Marcos Springs are maintained to protect endangered and threatened species to the extent required by federal law." ${ }^{98}$ In 1996, after three years of litigation and revised plans, the USFWS finally published an acceptable recovery plan.

\section{B. Bragg v. Edwards Aquifer Authority}

In Bragg v. Edwards Aquifer Authority, the Texas Supreme Court limited the rule of capture slightly. ${ }^{99}$ The court extended the notion of the waste exception on the rule of capture by holding that the "[a]uthority to prevent waste... refers... to the broader concept of preventing waste by conserving, protecting, and preserving the aquifer the aquifer through the Legislature's designated permit system." 100 In Bragg, the plaintiffs sought permits to withdraw groundwater in order to irrigate commercial pecan orchards. The EAA's general manager recommended denying the permit for one well because no water had been withdrawn during the historical use period and recommended a smaller allotment of water for the other well. ${ }^{101}$ The EAA's authority was upheld in this case allowing for limitations on the rule of capture within the area affecting the Edwards Aquifer.

\footnotetext{
${ }^{96}$ Id. at $* 29-30$.

${ }_{97}$ S. 1477, 73d Leg., Reg. Sess. (Tex. 1993).

${ }^{98}$ Ch 621, 1995 Tex. Gen. Laws 1.14(h).

9971 S.W.3d 729 (Tex. 2002).

${ }^{100}$ Id. at 736; Tex Gov't Code 2007.003(b)(11)(C) (Vernon 2000).

${ }^{101}$ Bragg, 71 S.W.3d at 732.
} 


\section{SHORTCOMINGS OF THE ENDANGERED SPECIES ACT}

The Endangered Species Act has been the major tool by which the rule of capture has been limited, but it is not sufficient if we are to protect the ecosystems that rely on groundwater. The shortcomings of the ESA have been well documented. ${ }^{102}$ The purpose of the ESA is to protected specific species that are near extinction. ${ }^{103}$ This purpose highlights the first shortcoming of the ESA, threshold qualification. The ESA defines an endangered species as "any species which is in danger of extinction throughout all or a significant portion of its range." 104 A threatened species is defined as "any species which is likely to become an endangered species within the foreseeable future throughout all or a significant portion of its range." 105 These definitions create a dangerously high threshold of endangerment before action can be taken. By the time a species "qualifies" for endangered species status, it may be too late for recovery. ${ }^{106}$

A second shortcoming of the ESA is the focus itself of the ESA: species. This focus is faulty for a number of reasons. The interdependent nature of species dictates that successful recover is better achieved at the ecosystem level than at the species level. ${ }^{107}$ Change is a natural part of the environment and species need to be able to adapt to the changes in their communities through these interdependencies. ${ }^{108}$ Further, focusing on species is more costly than focusing on broader categories of flora and fauna or on ecosystems as a whole. ${ }^{109}$

The interdependence argument forms the basis for why species level management is often ineffective and inefficient. A recent example highlights this point. Off the Aleutian Island of Alaska, sea otters populations have been decimated. ${ }^{110}$ The otters eat sea urchins,

${ }^{102}$ See John Charles Kunich, Preserving the Womb of the Unknown Species with Hotspots Legislation, 52 Hastings L.J. 1149 (2001) (from which much of this section comes), Daniel J. Rohlf, Six Biological Reasons Why the Endangered Species Act Doesn't Work - And What to Do About It, 5 Conservation Biology 273 (Sept. 1991); But see also Oliver A. Houck, On the Law of Biodiversity and Ecosystem Management, 81 Minn. L. Rev. 869 (1997)(arguing that the ESA has been effective).

${ }^{103}$ The Preamble of the ESA states that "[t]he purposes of this Act are to provide a means whereby the ecosystems upon which endangered species and threatened species depend may be conserved, to provide a program for the conservation of such endangered species and threatened species, and to take such steps as may be appropriate to achieve the purposes of the treaties and conventions set forth in subsection (a) of this section." 16 U.S.C. $\$ 1531(\mathrm{~b})(2000)$.

${ }^{104} 16$ U.S.C. $\$ 1532(6)$.

${ }^{105} 16$ U.S.C. $\$ 1532(20)$.

${ }^{106}$ The problems that a species as well as those trying to save the species must overcome once it has reached this threshold include loss of genetic diversity, usually depleted habitat, risk of extinction through random chance or natural disaster, as well as larger costs to nurse a small group back to a viable population.

${ }^{107}$ Mark L. Shaffer, Minimum Population Sizes for Species Conservation, 31 Bioscience 131 (1981).

${ }^{108}$ Jeffrey A. McNeely et al., Conserving the World's Biological Diversity, 57 (1990)

${ }^{109}$ J. Michael Schott et al., Species Richness: A Geographic Approach to Protecting Future Biological Diversity, 37 Bioscience 782, 783 (1987).

110 See "Alaska Sea Otters' Disappearance a Mystery," www.cnn.com2004/TECH/science/02/04/ otter.mystery.reut// (last accessed February 22, 2004). 
which eat kelp. Without otters to eat to control the urchin population, the local kelp forests are being decimated. One possible theory to explain the fall in otter populations is that orcas are feeding of otters since their normal prey, other whales, sea lions, and harbor seals, have seen reduced populations. Protecting one species at a time here, say sea lions, does not confront the main issue: scarcity of prey for orcas. In order to protect the biodiversity off the Aleutian Islands, a broader approach to the marine ecosystem is needed.

An additional problem with the ESA is the lack of a priority system for species protection. The ESA allows for "consideration of the economic impact" when designating critical habitat, ${ }^{111}$ but not for determining which species should be listed as endangered or threatened. ${ }^{112}$ There are many considerations one could have in constructing a priority system. A priority system, though, does entail problems.

The first is how to construct the schemes. Priority could be based on helping the most endangered species. This scheme, though, would be fraught with problems as many of these species may be past the point of revitalization given the ESA's threshold requirements. Priority could be based on "value" or "importance," but this system, too has problems. Since we only have identified a portion of world's species, it is incredibly unlikely that we even know of the potential benefits (genetically, medicinally, etc.) that can be derived from many species. What is important today may not be important tomorrow; further, technology may make species $\mathrm{X}$ infinitely important tomorrow, when it is has little value today.

Second, many priority systems entail an anthropocentric approach to protection and conservation. Priority schemes that focus on "value" or "charismatic megafauna" 113 focus on the human perception of species protection without much regard for the "ecosystemic" perception of species protection. Priority systems may entail problems, but without any ranking system, the ESA is even less effective and focused.

An additional shortcoming of the ESA is its lack of emphasis on multiple population maintenance. Multiple populations increase the likelihood for species survival by reducing catastrophic risk and increasing genetic diversity, and thus adaptation. The ESA defines "species" as "any subspecies of fish or wildlife or plants, and any distinct population segment of any species of vertebrate fish or wildlife which interbreeds when mature." 114 This is the only mention of different populations of species. Multiple populations are crucial to the long term survival of many species. By the time a species is listed it could have one population of limited numbers or multiple populations with unviable numbers. In either case, the ultimate survival of the species is greatly imperiled.

\footnotetext{
${ }^{111} 16$ U.S.C. 1533 (b)(2).

11216 U.S.C. $1533(\mathrm{~b})(1)(\mathrm{A})$.

${ }^{113}$ Rohlf, supra note 102 , at 275.

${ }^{114} 16$ U.S.C. $\$ 1532(16)$.
} 


\section{SENATE BILL 1 AND GROUNDWATER CONSERVATION DISTRICTS}

On June 1, 1997, the Texas legislature enacted Senate Bill 1 (SB1). ${ }^{115}$ In SB1, the legislature overhauled state water law and policy, but failed to adequately address the rule of capture or the effects on environmental concerns of groundwater management. SB1 does recognize the interconnectedness of surface water and groundwater and requires that decisions on permits take into account the effects on groundwater and groundwater recharge. ${ }^{116}$ But this provision addresses surface water rights and their affects on groundwater, not the effects of groundwater rights on surface waters.

In addressing the rule of capture, Senator Brown states that "groundwater management is best accomplished through locally-elected, locally-controlled groundwater conservation districts, thus providing that any modification or limitation on the rule of capture will be made by local groundwater districts." 117 The legislature sees these Groundwater Conservation Districts (GCD) as the preferred method of groundwater management. ${ }^{118}$ The legislature created GCDs for the "conservation, preservation, protection, recharging, and prevention of waste of groundwater" in Texas. ${ }^{119}$ The GCDs are authorized to promulgate rules that may limit groundwater rights. ${ }^{120}$ Individuals seeking to alter the size of a well or well pump or to operate a new well, must obtain a permit from the district. ${ }^{121}$ Among the issues the GCD must consider when evaluating a permit to drill a well or alter a well is "whether the proposed use of water unreasonably affects existing groundwater and surface water resources." ${ }^{\prime 22}$ By explicitly including the groundwater-surface water connection in the permit decision-making scheme, the legislature, even if only slightly, signaled that the end of the rule of capture may be neigh, but little action has been taken to further curtail the regime.

As argued above, groundwater extraction can have far reaching consequences. A GCD may be able to regulate groundwater if its jurisdiction encompasses the entire groundwater area, but for aquifers, like the Ogallala, that stretch across many states, the incentives for the local GMD to manage that aquifer are drastically different. SB1 does not 7. lequately address the rule of capture, does not adequately take into account the environmental ramifications of GMD decisions, and does not adequately deal with transboundary groundwater issues.

\footnotetext{
${ }^{115}$ Act of June 1, 1997 [S.B. 1], 75th Leg., R.S., ch 1010, 1997 Tex. Gen. Laws 3610 (codified at Tex. Health \& Safety Code $\int \S 341.0315, .0351-.0356, .0485, .049$, Tex Tax Code $\$$; See Senator J.E. "Buster" Brown, Senate Bill 1: We've Never Changed Texas Water Law This Way Before, 28 St. B. Tex. Envtl. L.J. 152 (1998).

${ }^{116}$ Tex. Water Code Ann. \$S 11.134(b)(3)(D), 11.151.

${ }^{117}$ Brown, supra note 115 , at 157 (referring to Tex. Water Code Ann. $\ 36.0015$ ).

${ }^{118}$ Tex. Water Code Ann. $₫ 36.0015$.

${ }^{119}$ Id.

${ }^{120}$ Tex. Water Code Ann. \$ 36.002

${ }^{121}$ Tex. Water Code Ann. $\$ 36.113($ a) and Tex. Water Code Ann. $\$ 36.115(a)$.

${ }^{122}$ Tex. Water Code Ann. $\$ 36.113$ (d)(2) (emphasis added).
} 


\section{THE CONSTITUTIONALIZATION OF ENVIRONMENTAL LAW IN BRAZIL}

One of the striking differences between American environmental law and Brazilian environmental law is the built in environmental guarantees in the Brazilian constitution. The constitutionalization of environmental protection is a phenomenon common to many countries who wrote their constitutions subsequent to the environmental movement of the 1970s, including Greece, Portugal, Spain, and Brazil. ${ }^{123}$ The fact that environmental concerns are enunciated in the constitution effects the legal development of a country in two important and related ways. First, a constitution provides the general lens through which all other laws must be seen. Subsequent laws must be interpreted in light of the highest law of the land, the constitution, thus all laws must concord with the fundamentals established in the constitution. Second, the constitution reflects the country's concerns and shapes national dialogue. Censorship and the need for a free exchange of ideas was a main concern of the framers of the American Constitution; thus, freedom of speech attained a primary role in the Constitution. More than two hundred years later, debates over educational material, artwork, media relations, and many other issues are constructed within the realm of freedom of speech.

The Brazilian Constitution sets forth a number of environmental rights as well as distributes competencies to different levels of government. Article 225 sets forth the basic right to a clean environment:

Todos têm direito ao meio ambiente ecologicamente equilibrado, bem de uso comum do povo e essencial à sadia qualidade de vida, impondo-se ao Poder Público e à coletividade o dever de defendê-lo para as presentes e futures gerações. ${ }^{124}$

Beyond this basic right, the Constitution establishes a number of rights that are not specific to environmental protection, but can be invoked to protect individuals from environmental damage: ${ }^{125}$ right to life, ${ }^{126}$ right to health, ${ }^{127}$ right to property, ${ }^{128}$ right to information, ${ }^{129}$ rights of indigenous peoples, ${ }^{130}$ and the right to public civil action. ${ }^{131}$

${ }^{123}$ Antônio Herman V. Benjamin, Introdução ao Direito Ambiental Brasileiro, Cadernos do Programa de Pós-Graduação em Direito - PPGDir./UFGRS, vol. II, núm V (2004), 94, 99.

${ }^{124}$ Constituição Federal, art. 225, caput.

125 Benjamin, supra note 124, at 103 (making distinction between explicit and implicit environmental rights).

${ }^{126}$ Constituição Federal, art 5, caput.

${ }^{127}$ See, Constituição Federal, art 200.

${ }^{128}$ Constituição Federal, art 5, inciso XXIII, and art. 186, inciso II.

${ }^{129}$ Constituição Federal, art 5, incisos XIV and XXXIIr.

${ }^{130}$ Constituição Federal, art 231, \& 1.

${ }^{131}$ Constituição. Federal, art 129 , inciso III, and $₫ 1$. 
The Brazilian Constitution divides competencies into: those unique to the federal government; ${ }^{132}$ those common to the federal government, the states, the federal district, and cities; ${ }^{133}$ those concurrent to the federal government, the states, and the federal district; ${ }^{134}$ those unique to the states; ${ }^{135}$ those unique to the cities; ${ }^{136}$ and those unique to the federal district. ${ }^{137}$ For each of these groups, the constitution assigns some form of competency relating to the environment.

Additionally, the chapter on the environment, article 225, states that it is incumbent upon the Poder Público to preserve ecological processes, ${ }^{138}$ preserve genetic diversity, ${ }^{139}$ establish protected areas, ${ }^{140}$ supply environmental impact studies, ${ }^{141}$ control the utilization of techniques, methods, or substances that pose a risk to human health and the environment, ${ }^{142}$ promote environmental education and awareness, ${ }^{143}$ and protect flora and fauna from extinction. ${ }^{144}$ Thus, the Brazilian Constitution establishes a right to clean environment, and charges the government with the protection of the environment, while allocating competency for environmental protection at multiple levels.

\section{GROUNDWATER LAW IN BRAZIL}

The groundwater legal system stems from the Constitution and the "Lei das Águas." 145 As mentioned above, the basic rights enumerated in the Constitution shape the structure of groundwater system.

Groundwater law in Brazil is divided between the federal government and the state governments. Article 22 of the Constitution gives the federal government the exclusive power to legislate over waters. The power to "lesgislar sobre águas" means the ability to set standards of quality and quantity as well as establish rules for the division and utilization of waters. ${ }^{146}$ The definition of waters as "bem de uso comum de povo"147 eliminates the

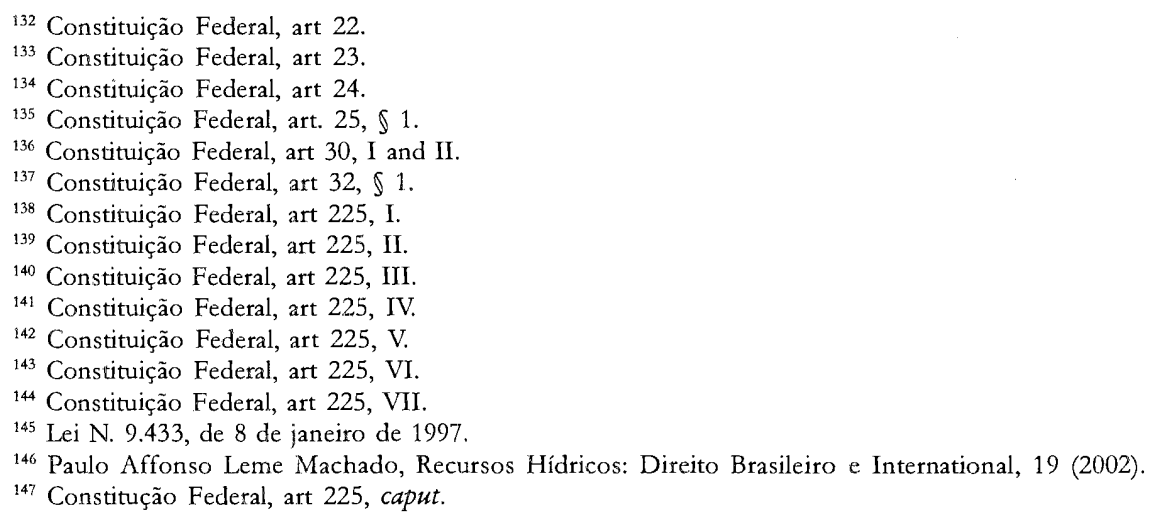


ability of an individual person to appropriate waters to the exclusion of others. ${ }^{148}$ This interpretation is underscored by the requirement that "extração de água de aqüifero subterrâneo para consumo final ou insumo de processo produtivo" is subject to the authorization of the government, ${ }^{149}$ and it is illegal "perfurar poços para extração de água subterânea ou opera-los sem a devida autorizaçao." "150 Interestingly, this law reverses the law established under the 1934 Water Code, which allows a type of correlative rights:

O dono de qualquer terreno poderá appropriar-se por meio de poços, galerias, etc., das águas que existam debaixo da suberfície de seu prédio contanto que não prejudique aproveitamentos existentes nem derive de seu curso natural águas públicas dominicais, públicas de uso comum ou particulares. ${ }^{151}$

Additionally, neither the federal government nor the state governments have the right to sell water commercially. ${ }^{152}$

While the constitution sets forth limits upon the use of groundwater, the constitution is less clear on the ownership of the groundwater. Under the Federal Constitution, "as águas superficiais ou subterâneas, fluentes, emergentes e em depósito" belong to the states. ${ }^{153}$

\section{GROUNDWATER LAW IN RIO GRANDE DO SUL}

Unlike Texas, Rio Grande do Sul has built in ecological considerations into its groundwater regime. By establishing the hydrological basin as the unit of administration for the governing water agency, Política Nacional de Recursos Hídricos, Rio Grande do Sul explicitly acknowledges the interaction between surface water and groundwater. ${ }^{154}$ This interaction is a consideration in water policy: "as interações com as águas superfíciais, observadas no ciclo hidrológico, sempre serão consideradas na administração do aproveitamento das águas subterrâneas." 155 Additionally, state agencies may:

Dada à necessária conservação das águas subterrâneas e a prioridade de abastecimento da população humana, ou por

\footnotetext{
${ }^{148}$ Machado, supra note 147, 25; Virgínia Amaral da Cunha Scheibe, O Regime Constitucional das Águas, Revista de Direito Ambiental, vol 25, 207, 210.

${ }^{149}$ Lei N. 9.433, de Janeiro de 1997, art. 12, II.

${ }^{150}$ Lei N. 9.433, de Janeiro de 1997, art. 49, V.

151 Decreto N. 24.643, de 10 de julho de 1934, art. 96.

${ }^{152}$ Machado, supra note 147, 29.

153 Constitução Federal, art 26, I.

${ }^{154}$ Lei N. 9.433, de 8 de janeiro de 1997, art. 1, V.

155 Rio Grande do Sul: Decreto N. 42.047, de 26 de dezembro de 2002, art. 3, parágrafo único.
} 
motivos geológicos, hidrológicos, geotécnicos ou ecológicos, poderão restringir a captação e o uso dessas águas, bem como instituir áreas de proteção dos aqüíferos. ${ }^{156}$

By explicitly acknowledging the hydrological link between ground and surface water and including ecological concerns in the decision making process, Rio Grande do Sul is constructing an integrated regime in which water management is in sync with environmental management.

Well monitoring is part of this integrated regime. Wells are required to have devices that monitor the amount and quality of water extracted, and well owners must report this in formation to the governing agency. ${ }^{157}$ Well owners must operate their wells "em condições adequadas, de modo a assegurar a capacidade do aqǘfero e evitar o desperdício de água." 158 Just as is the case in federal law, it is illegal in Rio Grande do Sul "executar a perfuração de poços ou a captação de água subterrânea sem a devida aprovação."159

\section{CONCLUSION}

Groundwater and surface water are hydrologically linked. Actions taken below ground affect water levels and ecosystems above ground. Environmental protection and water management need to be made in unison in order for either to be effective or efficient. Federal law in the United States does not establish an environmental basis for water policy. In Texas, two separate regimes govern the use of ground and surface waters. This lack of a coherent regime has many detrimental effects on biodiversity. The rule of capture, which governs groundwater, can lead to excessive pumping and the draining of streams and lakes that are connected to the aquifer. Many different types of species of plants and animals rely on the surface water, and sometimes on the groundwater. By not having conservation laws that impact the rates of groundwater pumping, Texas is in effect allowing land owners to drain the biodiversity through wells and pumps.

Brazil establishes the water basin as the administrative unit for water management, rather than any portions such as groundwater or surface water. In Rio Grande do Sul, the interaction between ground and surface water is explicitly recognized, and the need for ecological considerations in evaluating groundwater extraction is made explicit. Rio Grande do Sul, as well as other American states, have acknowledge the need for integrated water management and have taken steps to curtail excessive pumping and thus protect biodiversity.

${ }^{156}$ Rio Grande do Sul: Decreto N. 42.047, de 26 de dezembro de 2002, art. 27, caput. (emphasis added).

157 Rio Grande do Sul: Decreto N. 42.047, de 26 de dezembro de 2002, art. 24 \$1.

${ }^{158}$ Rio Grande do Sul: Decreto N. 42.047, de 26 de dezembro de 2002, art. 23.

${ }^{159}$ Rio Grande do Sul: Lei N. 10.350, de 30 de dezembro de 1994. 